\title{
Four promoters of IRF5 respond distinctly to stimuli and are affected by autoimmune-risk polymorphisms
}

\author{
Daniel N. Clark, R. Daniel Read, Vera Mayhew, Stephen C. Petersen, Lissenya B. Argueta, Lance A. Stutz, \\ Rodney E. Till, Sean M. Bergsten, Brandon S. Robinson, Douglas G. Baumann, J. Casey Heap and \\ Brian D. Poole*
}

Department of Microbiology and Molecular Biology, Brigham Young University, Provo, UT, USA

\section{Edited by:}

Timothy B. Niewold, Mayo Clinic, USA

\section{Reviewed by:}

Meredith O'Keeffe, Burnet Institute

for Medical Research, Australia

Eamon McGreal, Cardiff University,

UK

\section{*Correspondence:}

Brian D. Poole, Department of Microbiology and Molecular Biology, Brigham Young University, 857 WIDB,

Provo, UT 84604, USA

e-mail: brian_poole@byu.edu
Introduction: Autoimmune diseases such as systemic lupus erythematosus, rheumatoid arthritis, and multiple sclerosis affect millions of people worldwide. Interferon regulatory factor 5 (IRF5) contains polymorphisms associated with these autoimmune diseases. Two of these functional polymorphisms are found upstream of the IRF5 gene. rs2004640, which is a single nucleotide polymorphism and the CGGGG insertion/deletion (indel) were studied. IRF5 uses four different promoters for its four first exons: 1A, 1B, 1C, and 1D. Each promoter was analyzed, including functional differences due to the autoimmune-risk polymorphisms.

Results: IRF5 promoters were analyzed using ChIP-Seq data (ENCODE database) and the FactorBook database to define transcription factor binding sites. To verify promoter activity, the promoters were cloned into luciferase plasmids. Each construct exhibited luciferase activity. Exons $1 \mathrm{~A}$ and $1 \mathrm{D}$ contain putative PU.1 and NFkB binding sites. Imiquimod, a Toll-like receptor 7 (TLR7) ligand, was used to activate these transcription factors. IRF5 levels were doubled after imiquimod treatment $(p<0.001)$, with specific increases in the 1 A promoter (2.2-fold, $p=0.03$ ) and $1 \mathrm{D}$ promoter (2.8-fold, $p=0.03$ ). A putative binding site for p53, which affects apoptosis, was found in the promoter for exon 1B. However, site-directed mutagenesis of the p53 site showed no effect in a reporter assay.

Conclusion:The IRF5 exon 1B promoter has been characterized, and the responses of each IRF5 promoter to TLR7 stimulation have been determined. Changes in promoter activity and gene expression are likely due to specific and distinct transcription factors that bind to each promoter. Since high expression of IRF5 contributes to the development of autoimmune disease, understanding the source of increased IRF5 levels is key to understanding autoimmune etiology.

Keywords: IRF5, alternative promoters, autoimmune disease risk, interferon, systemic lupus erythematosus

\section{INTRODUCTION}

Alternative splicing is a method of making different transcripts from one genomic region. One type of alternative splicing involves the use of multiple first exons. This is termed alternative promoter splicing, since each first exon must have its own promoter. Alternative promoter splicing occurs in around half of human genes (1).

The gene interferon regulatory factor 5 (IRF5) is a transcription factor which controls immune signaling, cytokine expression, the cell cycle, and apoptosis (2-5). It exhibits alternative promoter splicing and has four different first exons that are currently known. The start codon for IRF5 is in exon 2, therefore the use of different first exons does not directly alter the protein sequence. Instead the four alternative promoters are four pathways to make the same protein. The first exons are 1A, 1B, 1C, and 1D.

The IRF5 gene contains several GWAS-identified polymorphisms associated with autoimmune diseases. Among them, most do not have an assumed effect. Although IRF5 contains several polymorphisms associated with autoimmunity, only four have been identified as functional polymorphisms (6). Two of these are in the promoter or untranslated regions of IRF5 where the polymorphisms may have a direct effect on IRF5 expression: a single nucleotide polymorphism (SNP) near exon 1B called rs2004640, and a copy-number variant near exon 1A called rs77571059 (Figure 1). The rs 77571059 polymorphism is an insertion/deletion (indel) of $5 \mathrm{bp}$, and is commonly referred to as a CGGGG indel. This study examines the promoters of IRF5, with information on how these two functional polymorphisms play a role in IRF5 expression. A general trend of these polymorphisms is to increase levels of IRF5.

The rs 2004640 SNP is a G or T polymorphism near the $3^{\prime}$ end of exon 1B. The SNP is within the splice junction, such that when the $\mathrm{G}$ allele is present, the splice junction is not recognized and exon 1B cannot be spliced onto exon 2 (8). Unspliced transcripts are usually targeted by non-sense mediated decay (9). The risk T allele at this locus is associated with systemic lupus erythematosus (SLE) in multiple ethnic groups $(8,10-13)$ rheumatoid arthritis $(14,15)$, systemic sclerosis $(16)$, multiple sclerosis $(17)$, ulcerative 


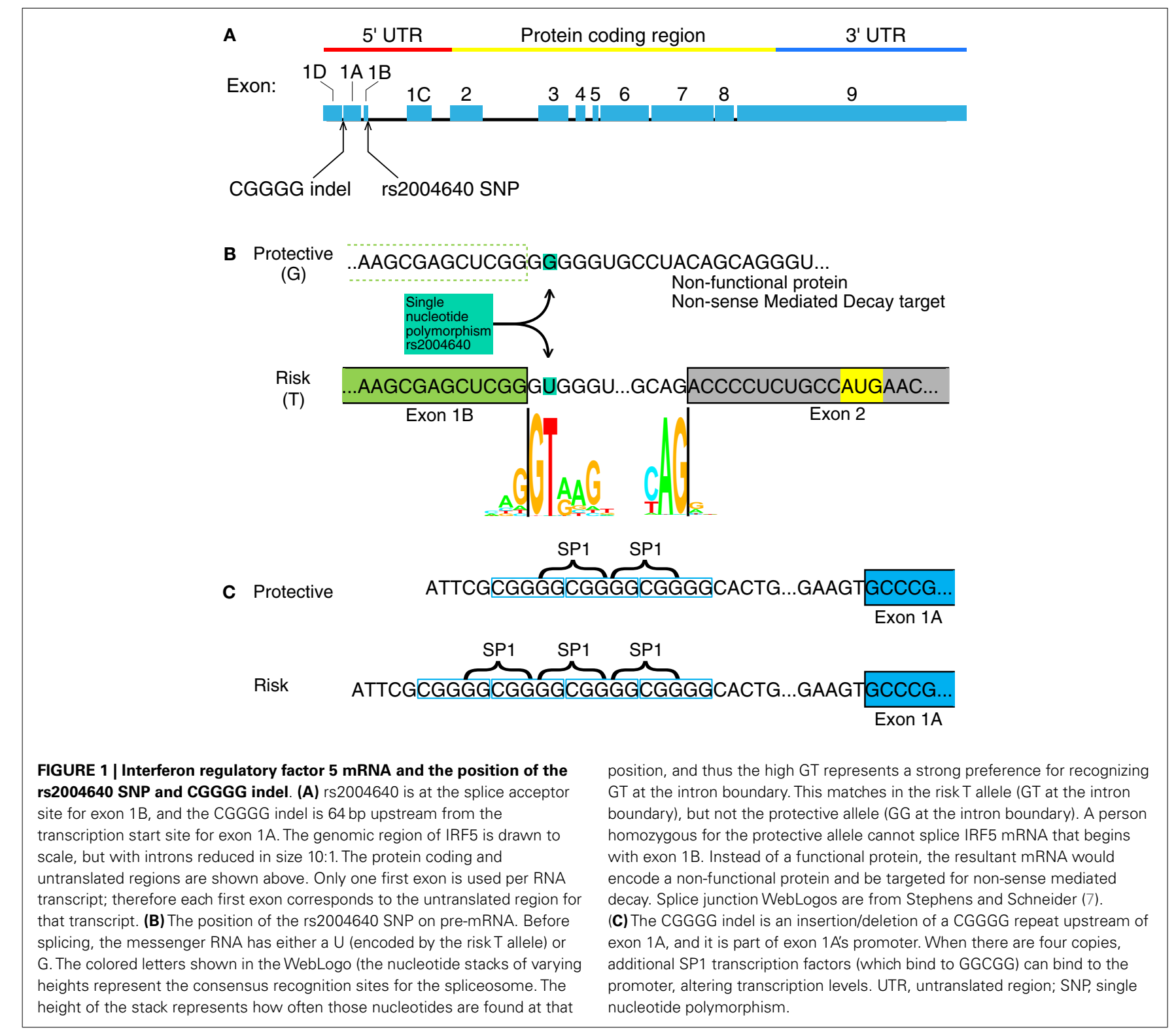

colitis (18), and Sjögren's syndrome (19). Autoimmune-risk haplotypes that include rs2004640 exhibit high IRF5 levels $(6,20)$, as well as high levels of IFN $\alpha$ and TNF $\alpha(21,22)$.

The CGGGG indel (rs77571059) is found $64 \mathrm{bp}$ upstream of the transcription start site for exon 1A. Each allele has either three $(3 \times)$ or four copies $(4 \times)$ of the CGGGG repeat sequence. The $4 \times$ copy-number variant allows binding of additional SP1 transcription factors (23). This $4 \times$ variant is associated with SLE (10), Sjögren's syndrome (24), multiple sclerosis (17), Crohn's disease and ulcerative colitis (18), and acute coronary syndrome (25). The CGGGG $4 \times$ variant is associated with increased expression of IRF5 itself (23), as well as TNF $\alpha$, IL-12p40, IL-8, IL-1b, and IL-10 (22).

Interferon regulatory factor 5 exons $1 \mathrm{~A}, 1 \mathrm{~B}, 1 \mathrm{C}$, and $1 \mathrm{D}$ each have a distinct transcriptional start site, and as is the case with every first exon, each exon 1 of IRF5 has its own promoter. IRF5's four promoters have not been thoroughly characterized, although previous studies on the $1 \mathrm{~A}$ and $1 \mathrm{C}$ exons' promoters revealed that they are controlled in part by an IRF element (IRFE) and an interferon stimulatory response element (ISRE), respectively (26). Herein, we identify and characterize a putative promoter for exon $1 \mathrm{~B}$, and hypothesize that the $1 \mathrm{~B}$ promoter would be active and regulated by stimuli that activate IRF5. We further hypothesize that the $1 \mathrm{~B}$ promoter would be regulated by $\mathrm{p} 53$.

Autoimmune diseases are caused by environmental triggers in those with a genetic propensity. Increases in IRF5 expression due to these promoter polymorphisms could lead to an autoimmunerisk state. A hallmark of lupus and those at genetic risk for lupus is the presence of heightened levels of interferon and interferonresponse genes; the interferon signature (27). IRF5 is a key gene in the interferon response to viral infection. IRF5 is a transcription factor whose activation leads to the interferon signature and the control of multiple genes involved in inflammation and immunity (28). It is primarily expressed in B cells, monocyte-derived cells, and plasmacytoid dendritic cells (pDCs) (2). 
For SLE, an environmental trigger is likely to be Epstein-Barr virus (EBV) infection $(29,30)$. EBV infection affects IRF5 and IRF7 signaling, and has been associated with lupus through several different mechanisms (30-32). Interestingly, EBV infection alters IRF5 splicing to produce a dominant negative variant, suppressing the interferon response (33). For these studies, EBV-infected B cells are used, because cells with the appropriate genotypes can be immortalized and used in multiple experiments. As B cells, these cells are relevant to autoimmune disease and express IRF5. The incorporation of EBV into the model cells means that our results must be interpreted with caution, as it is possible that the major effects of these risk polymorphisms regulate or alter EBV infection, not IRF5 directly. These results must therefore be interpreted with caution. However, if it is found to be the case that these IRF5 polymorphisms affect EBV infection, that would likely provide even more exciting directions to pursue given the potential relationship between EBV infection and lupus.

\section{RESULTS}

\section{IRF5'S FOUR PROMOTERS}

Interferon regulatory factor 5 uses one of four first exons for each molecule of mRNA - 1A, 1B, 1C, or 1D. Whether or not one of the four first exons of IRF5 would be actively transcribed depends on the cellular transcription factors that are able to bind it. A putative IRF5 exon 1B promoter sequence was identified by using the encyclopedia of DNA elements chromatin immunoprecipitation sequencing (ENCODE ChIP-Seq) data set (34). This analysis includes a list of transcription factors known to bind to the putative promoter sequence. An analysis of the promoters for each of the other three first exons of IRF5 was performed using the same database. This list represents results from many experiments which show transcription factors that bind to this genomic region of DNA (Figure 2A).

The transcription factors listed have also been associated with specific binding sites. WebLogos, which visualize consensus

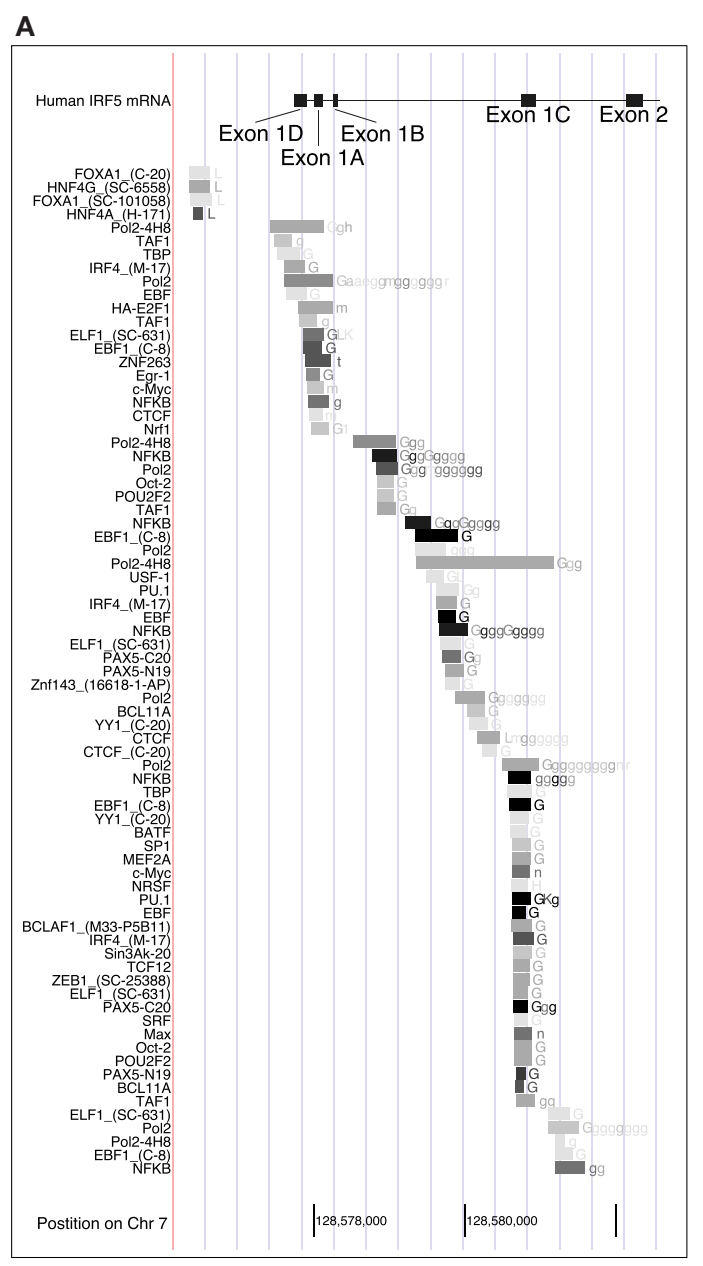

FIGURE 2 | Promoter analysis of each first exon of IRF5. (A) ENCODE data shows results of ChIP-Seq analyses in the promoter region of IRF5. (B) The consensus search terms generated from FactorBook, with the TCF12 consensus binding site as an example (35). This data was used to manually define the nucleotide search terms shown. (C) The final analysis of potential binding sites is shown along the genomic DNA promoter sequences, with

B

TCF12

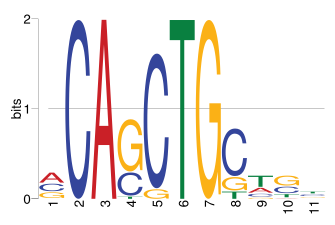

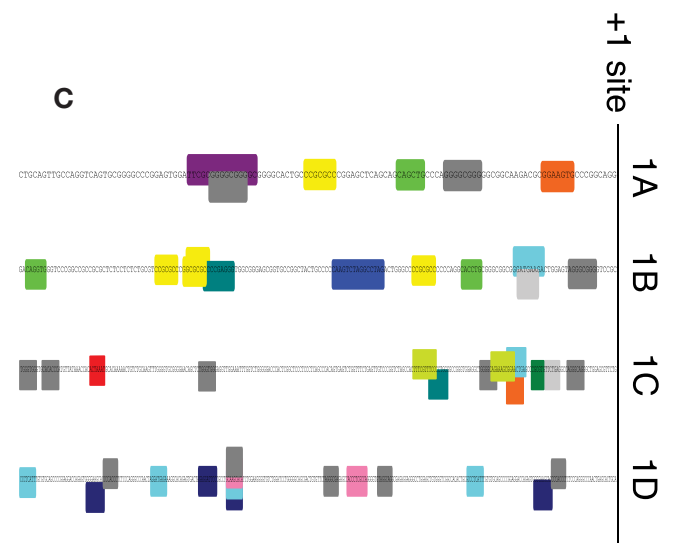

color-coded boxes representing the binding sites or transcription factors shown in the key. AP, activator protein; BRE, B-response element; CTCF, CCCTC binding factor; TCF, transcription factor; EBF, early $B$ cell factor; IRF, interferon regulatory factor; $N F_{K} B$, nuclear factor kappa light chain enhancer of activated B cells; PAX, paired box; PU, purine rich; SP, specificity protein; STAT, signal transducer and activator of proteins; TATA, thymidine adenine. 
binding sites (36), were generated de novo for each ENCODE transcription factor tested, and compiled in the online database FactorBook (35). The consensus sites were converted manually into an ambiguous DNA code search term, where for example W (weak) represents an A or a T nucleotide (Figure 2B). The consensus search term was then used to search the proximal promoters ( $\sim 200$ bp upstream from the +1 sites) to encounter a proposed binding site. Consensus search term screening was performed using MEGA (37).

Several transcription factors' binding sites were found in the regions upstream of transcription start sites (Figure 1C). The start sites were taken from reference sequences for exons $1 \mathrm{~A}, 1 \mathrm{~B}$, and $1 \mathrm{C}$, and the sequence for variant 12 of IRF5 for exon 1D (no reference sequence exists at present for exon 1D). The source sequences are GenBank IDs NM_002200.3, NM_032643.3, NM_001098627.2, and EU258897.1 for exons 1A, $1 \mathrm{~B}, 1 \mathrm{C}$, and $1 \mathrm{D}$, respectively. The workflow and results are shown in Figure 2, with transcription factor 12 (TCF12) as an example.

\section{EACH IRF5 PROMOTER EXHIBITS TRANSCRIPTIONAL ACTIVITY}

The promoters for the four first exons of IRF5 contain different potential transcription factor binding sites. The $1 \mathrm{~A}$ promoter contains putative binding sites for paired box 5 (PAX5), PU.1, SP1, and TCF12 which binds to enhancer boxes (E boxes). An extra SP1 binding site appears in those with the CGGGG $4 \times$ indel. Exon 1B's promoter was the only IRF5 promoter with a p53 binding site. This is discussed in more detail below. 1B also has SP1, TCF12, IRF4, and early B cell factor (EBF) sites. The 1C promoter was the only promoter with STAT2, activator protein 1 (AP1), and Myc binding sites; it also has SP1 and IRF4 sites. The 1D promoter evaluation showed potential binding sites for only four transcription factors: SP1, CCCTC binding factor (CTCF), IRF4, and NFKB.

To determine activity levels of each promoter, they were cloned using PCR and inserted into luciferase reporter plasmids. In addition to the $1 \mathrm{~B}, 1 \mathrm{C}$, and $1 \mathrm{D}$ promoters, there are two distinct versions of the 1A promoter, representing the two rs77571059 polymorphisms. One has the $4 \times$ variant of the CGGGG indel $\left(1 \mathrm{~A}_{\text {risk }}\right)$, and the other has the $3 \times$ variant $\left(1 \mathrm{~A}_{\text {protective }}\right)$. The $1 \mathrm{~B}$ promoter was cloned using nested PCR to avoid an inverted repeat sequence located $\sim 2 \mathrm{kbp}$ upstream. The inverted repeat is $1.8 \mathrm{kbp}$ in length, and the two copies have $82.8 \%$ identity (34).

A luciferase assay was performed using the pGL4 plasmid. The promoters of IRF5 were inserted upstream of the luciferase gene and promoter activity was evaluated by measuring luminescence. The activity levels of the promoters were analyzed in several cell types since distinct transcription factors would be active in different cell types. Three types of immune cells were used: lymphoblastoid cell lines (LCLs), EBV-transformed human B cells that were generated from three healthy volunteers; U937 cells, a commercially available human monocyte cell line; and Jurkat cells, a commercially available human $\mathrm{T}$ cell line. Jurkat cells were used as the negative control, since $\mathrm{T}$ cells do not express high levels of IRF5. Cells were electroporated with each of the IRF5 promoter luciferase plasmids. A second plasmid, which expresses enhanced green fluorescent protein (eGFP), was cotransfected as a transfection control for each construct (38). Values for luciferase expression were then normalized to the fluorescence level to account for transfection efficiency.

Luciferase assay results showed that the $1 \mathrm{~A}$ promoters $\left(1 \mathrm{~A}_{\text {risk }}\right.$ and $\left.1 \mathrm{~A}_{\text {protective }}\right)$ demonstrated significantly higher transcriptional activity than the other three promoters in LCL and Jurkat cells ( $p=0.0009$ and $p=0.016$, respectively) (Figure 3). As expected,

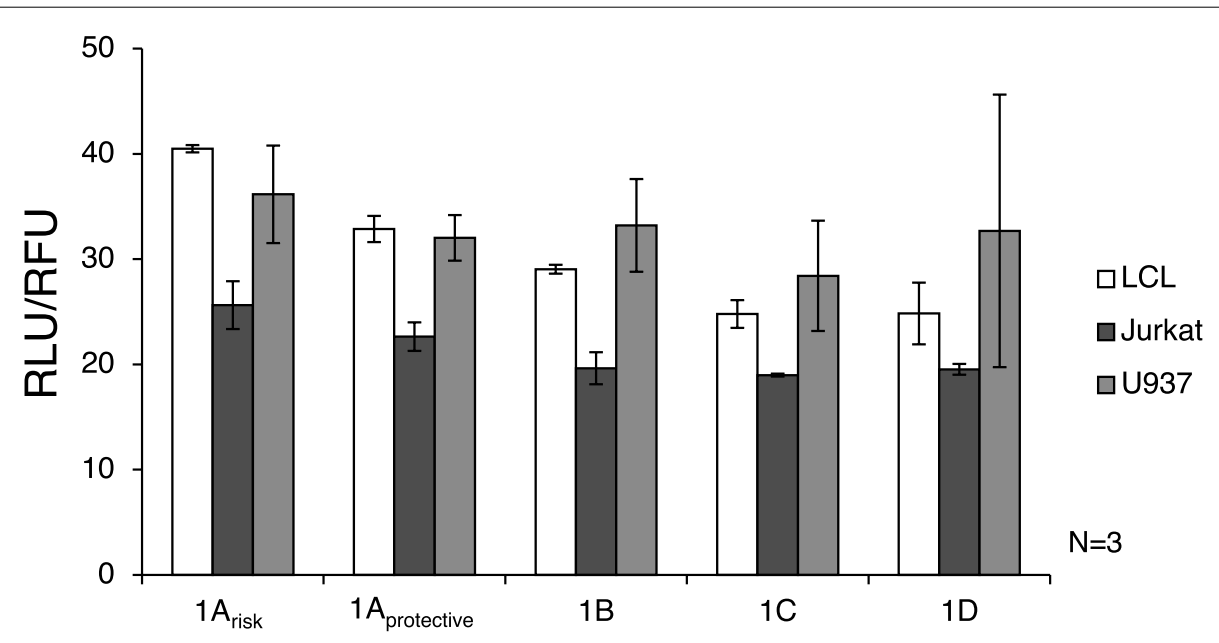

FIGURE 3 | Interferon regulatory factor 5 promoter activity in immune cells. The luciferase plasmids were transfected by electroporation of three cell types: LCL, U937 cells, and Jurkat cells. A control GFP-encoding plasmid was also used in each sample to normalize transfection efficiency. ANOVA analysis revealed statistically significant variation between groups $(p=0.014)$; therefore $t$-tests were used to determine where the variation was found. The levels of transcription were significantly lower in Jurkat cells compared to LCL and U937 cells ( $p<0.01)$. IRF5 is not highly expressed in $\mathrm{T}$ cells such as Jurkat cells, but is normally expressed in B cells and monocytes (39). The $1 \mathrm{~A}$ promoters $\left(1 \mathrm{~A}_{\text {risk }}\right.$ and $\left.1 \mathrm{~A}_{\text {protective }}\right)$ displayed higher activity than the $1 \mathrm{~B}, 1 \mathrm{C}$, or $1 \mathrm{D}$ promoters in $L C L$ and Jurkat cells ( $p=0.0009$ and $p=0.016$, respectively). In LCLs the $1 \mathrm{~A}_{\text {risk }}$ promoter activity was higher than $1 \mathrm{~A}_{\text {protective }}$ promoter activity $(p=0.019)$. The putative $1 \mathrm{~B}$ promoter acted like the $1 \mathrm{~A}$ promoter in that expression was significantly higher in LCLs than in Jurkat cells $(p=0.027)$. LCL, lymphoblastoid cell line; $\mathrm{RLU}$, relative luminescence units; RFU, relative fluorescence units. In some samples, the first exon was not detectable, which is why there is some variation in sample number. 
expression from all IRF5 promoters was significantly lower $(p<0.01)$ in Jurkat cells when compared to U937 or LCL cells. When comparing LCL to U937 cells, there was no significant difference in IRF5 promoter activity $(p=0.38)$.

The autoimmune-risk polymorphisms affected the activity of the promoters. In LCLs the $1 \mathrm{~A}_{\text {risk }}$ promoter activity was significantly higher than $1 \mathrm{~A}_{\text {protective }}$ promoter activity $(p=0.019)$. The $1 \mathrm{~B}$ promoter, which is only relevant when the risk allele rs2004640 is present, showed activity in LCLs and U937 cells, indicating that it is an active promoter in the same cell types as the other promoters.

\section{THE 1A AND 1D PROMOTERS ARE AFFECTED BY TLR7 LIGATION}

The levels of IRF5 expression increase due to several signaling pathways, one of which is the Toll-like receptor 7 (TLR7) pathway. Endosomal TLRs such as TLR7 require the ligand to first be endocytosed into the cells, and then merged with the endosome that contains TLR7. Most endosomal TLRs bind to nucleic acids.

Toll-like receptor 7 ligation is an important method of activation for pDCs $(40,41)$. pDCs can produce large amounts of interferon alpha in response to immunostimulatory molecules such as nucleic acids. This is an important activation pathway in autoimmune disease (42). Single stranded RNA is the natural agonist for TLR7. TLR7 can also be activated by small synthetic compounds such as the imidazoquinolines, namely imiquimod and resiquimod. Imiquimod is a TLR7 ligand and resiquimod is a ligand for TLR7 and TLR8 (43). Imiquimod is used clinically as a topical cream as a form of treatment for genital warts and certain cancers. It activates the immune system, recruiting inflammatory mediators to kill the virus-infected or cancerous cells (44).

To verify that imiquimod treatment was stimulating the cells through TLR7, gene expression of interferon-response genes and cytokine gene expression were monitored using real-time PCR. Imiquimod stimulation led to significantly increased expression of the interferon-induced genes CCR7 and NOXA, while expression of the calreticulin was not significantly affected (Figure 4). Expression of the genes for the cytokine IL- 6 was substantially upregulated (71-fold increase, $p=0.028$ ). IL-6 expression is a common readout for stimulation through TLR7 $(45,46)$. Expression of the cytokine IL-10 is also significantly, though slightly, increased (1.5-fold, $p=0.038$ ) after treatment with imiquimod (Figure 4). These results indicate that imiquimod treatment did in fact stimulate the cells.

Imiquimod treatments were performed to determine the effects of stimulation on the activity of each IRF5 promoter. First exonspecific quantitative PCR was used to determine changes in the levels of each first exon after imiquimod stimulation. Cells were treated with imiquimod at $25 \mu \mathrm{g} / \mathrm{ml}$ for $24 \mathrm{~h}$, and then cDNA was prepared from an RNA extract of treated cells. This was done for LCLs generated from 20 healthy individuals. As expected, IRF5 levels increased when cells were treated with imiquimod a 1.9-fold increase when normalized to the housekeeping gene, $\beta$-glucuronidase ( $\beta$-GUS) (Figure 5A).

The amounts of each first exon were also measured and compared to $\beta$-GUS by quantitative PCR. Several samples yielded undetectable levels of first exon transcripts, and were thus not

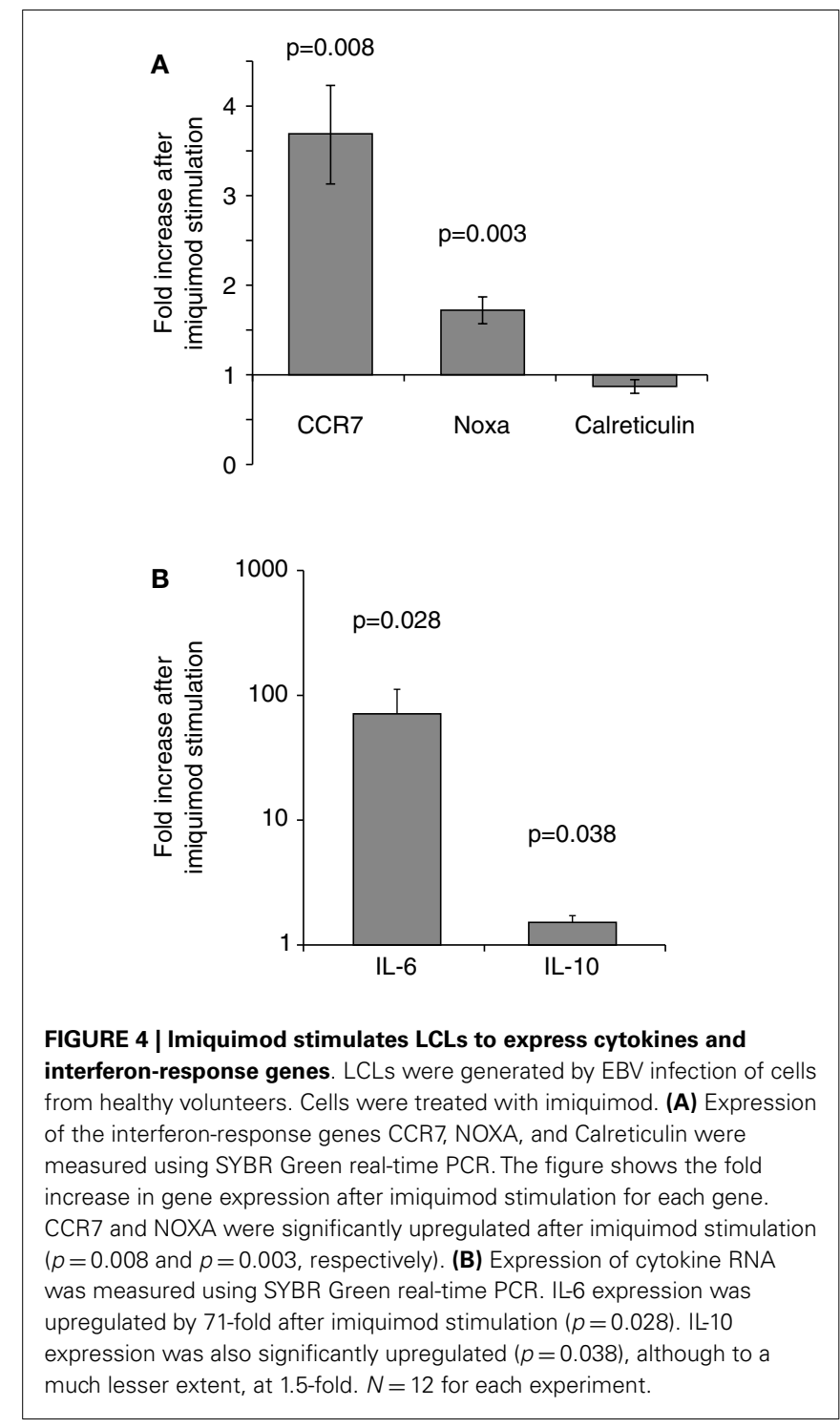

included in the analysis, resulting in the variation in sample number noted in Figure 5. The levels of exons 1A and 1D increased by at least twofold after treatment with imiquimod when compared to $\beta$-GUS (Figure 5B).

The effect of the rs2004640 polymorphism on imiquimod stimulation on was examined using real-time PCR. LCLs with risk or protective genotypes were stimulated with imiquimod, and the change in expression of interferon-stimulated genes was compared between risk and protective cells. IRF5 expression was higher in risk cells by nearly 1.7-fold ( $p$-0.021). CCR7 did not increase as much after imiquimod stimulation in the risk cells compared to the protective ( 0.77 -fold, $p=0.05)$. However, the risk cells demonstrated a small increase in NOXA expression after imiquimod stimulation, and the Calreticulin levels decreased less (by 1.35-fold, $p=0.05$ ) in the risk cells than in the protective (Figure 6). These results show a small, but consistent increase in responsiveness to imiquimod stimulation in the cells with the risk allele. 

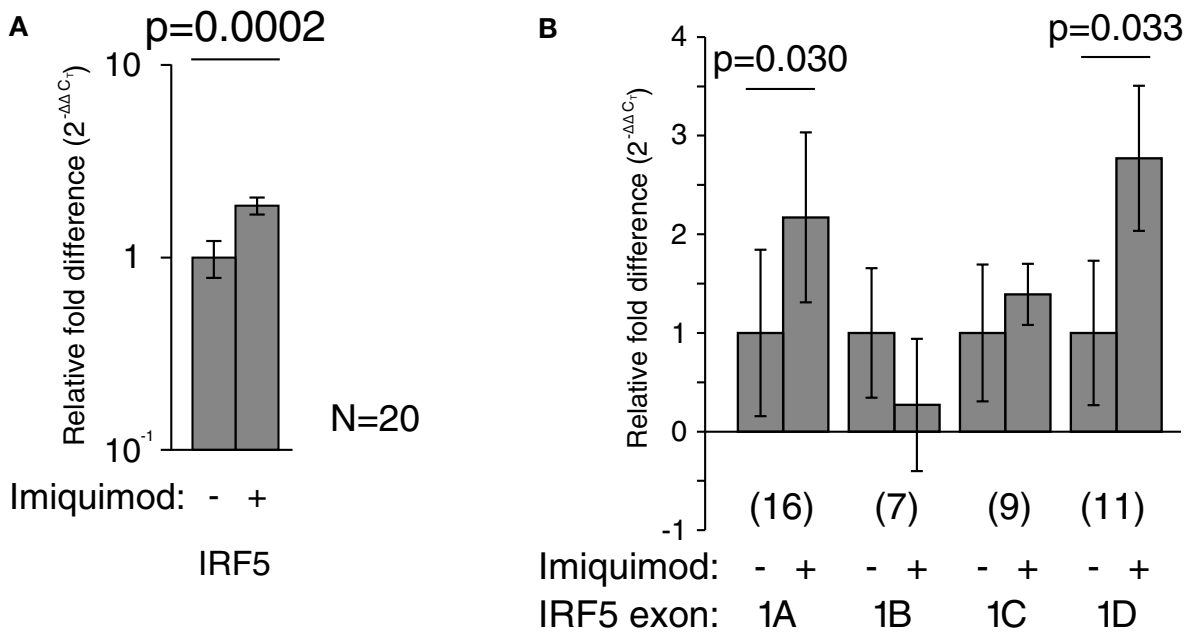

FIGURE 5 | Imiquimod caused increased IRF5 transcription through exons 1A and 1D. All mRNA levels were measured in LCLs generated from healthy individuals. Levels were determined by TaqMan-based quantitative PCR using the $2^{-\triangle \Delta C T}$ method. (A) The levels of IRF5 were 1.9-fold higher in treated cells $(p=0.0002)$. (B) The levels of exon $1 \mathrm{~A}$ increased 2.2 -fold $(p=0.030)$ and exon 1D increased by 2.8-fold $(p=0.033)$. All fold-increase values were normalized to the $\beta$-GUS housekeeping gene. The numbers in parentheses indicate the sample size. Analysis of variance was performed including each first exon and stimulation state as groups. This analysis revealed statistically significant variation $(p<0.0001)$. Statistical significance between individual groups was determined by paired $t$-test. IRF, interferon regulatory factor.
The effect of EBV infection on IRF5 expression and imiquimod stimulation were analyzed. Ramos cells, a B cell line that is similar to LCL but is EBV negative, were stimulated with imiquimod and expression of IRF5 was compared to IRF5 expression in LCLs. After two experiments, there was a $<1.2$-fold difference in IRF5 expression between the EBV positive and EBV-negative cell lines. After imiquimod stimulation, there was similarly only a very small difference between the EBV positive LCL and EBV-negative Ramos cells (Figure 6B).

\section{THE rs2004640 SNP'S ROLE IN p53 BINDING AND ACTIVATION}

Mutagenesis of the $1 \mathrm{~B}$ promoter p53 binding site did not alter transcriptional activity.

The promoter analysis described above revealed a potential p53 binding site. $\mathrm{p} 53$ binds as a tetramer to two copies of the sequence rrCwwGyyy, with a spacer of 0-13 nt between the copies (189). A close match to this sequence was found in the $1 \mathrm{~B}$ promoter (Figure 7B). This is suggestive because of the potential role IRF5 may play in apoptosis dysregulation in SLE. IRF5 is also proapoptotic in a p53-independent manner (47), and thus if p53 activates IRF5, apoptosis levels would be additively altered. Should p53 can control the $1 \mathrm{~B}$ promoter, apoptosis would be altered in rs2004640 risk cells because the $1 \mathrm{~B}$ promoter is only used in cells with the rs2004640 risk allele.

To test whether activated p53 protein can indeed bind to the p53 binding site, the plasmid which contains the $1 \mathrm{~B}$ promoter was mutated using site-directed mutagenesis. Mutations were made to the wild-type sequence such that p53 should not be able to bind. The consensus binding site contains four conserved $\mathrm{C}$ or $\mathrm{G}$ bases which were mutated to $\mathrm{A}$ or $\mathrm{T}$ on the luciferase plasmid (Figure 7B). The wild type and p53-mutant luciferase plasmids were transfected by electroporation into three different LCLs generated from healthy volunteers. After $24 \mathrm{~h}$ to allow for plasmid expression, cells were either treated with etoposide or left untreated for $48 \mathrm{~h}$. The levels of luciferase activity stayed fairly constant in the wild-type plasmid when treated with the etoposide. However, when the p53 binding site was mutated, thus inhibiting binding of p53, there is an slight, but non-significant increase in activity when treated with the etoposide versus being left untreated (Figure 7A). This finding suggests that if p53 does in fact bind to the IRF5 exon 1B promoter, it is likely inhibitory rather than stimulatory.

\section{DISCUSSION}

The CGGGG indel polymorphism within the 1A promoter has previously been shown to alter transcription factor binding. When cells have the $4 \times$ variant, an additional SP1 binding site is created. This has been shown to increase IRF5 in PBMCs (48), but decrease 1A-specific IRF5 transcripts in thymic cells (49). Both versions of the 1A promoter showed activity in HEK293T cells and Raji cells. As expected, SP1 sites were found in our analysis of the 1A promoter, including an extra SP1 binding site in those with the CGGGG $4 \times$ indel. SP1 is active during development, cell growth, apoptosis, differentiation, and immune and DNA damage responses (50).

The 1A promoter has a PAX5 binding site, a gene that activates $B$ cells at early, but not late stages of development (51). There is an E box, and TCF12 is a member of the basic helix-loop-helix group of transcription factors which binds to E boxes (52). TCF12 was shown to bind somewhere in the promoter region of IRF5 in the ENCODE dataset (34), and the putative E box in 1A's promoter is a likely site. TCF12 is known to be expressed in B cells and T cells (39). A PU.1 site is in the 1A promoter as well; PU.1 activates gene expression during B cell development and in myeloid cells (53). 


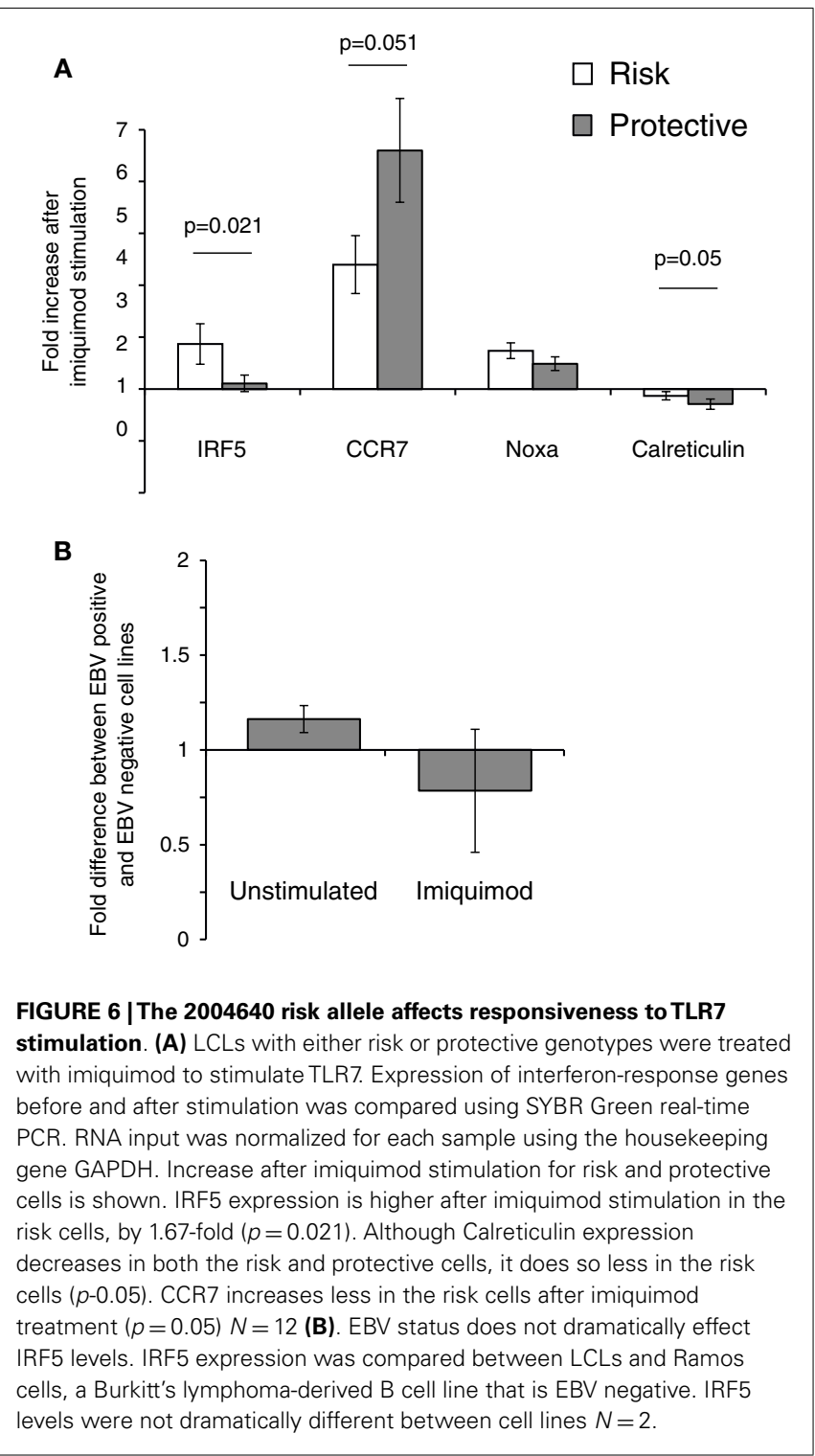

The 1A promoter showed increased activity when cells were stimulated with the TLR7 agonist imiquimod. This may be through the PU.1 site through IRF7. IRF7 is known to be activated by TLR7 (54), and PU.1 binds to a similar GAAN $_{(\mathrm{N})}$ GAA motif to IRFs. Further work is necessary to determine in which cell types or with which stimuli the 1A promoter is most active, and in what instances the CGGGG $4 \times$ variant alters this activity.

A previous report by Mancl et al. evaluated the $1 \mathrm{~A}$ and $1 \mathrm{C}$ promoters (26). The $1 \mathrm{~A}$ promoter was activated by herpes simplex, Newcastle disease and vesicular stomatitis viruses in PBMCs, Daudi, and THP-1 cells; respectively; as evidenced by increased transcription of IRF5. A luciferase reporter gene assay also showed that IRF5's 1A promoter is constitutively active and contains an IRFE consensus binding site. However, the promoter region used was a 596-bp region determined by a $5^{\prime}$ rapid amplification of cDNA ends ( $5^{\prime}$ RACE) experiment and is 939 bp upstream of the GenBank reference sequences for exon 1A, and even extends past

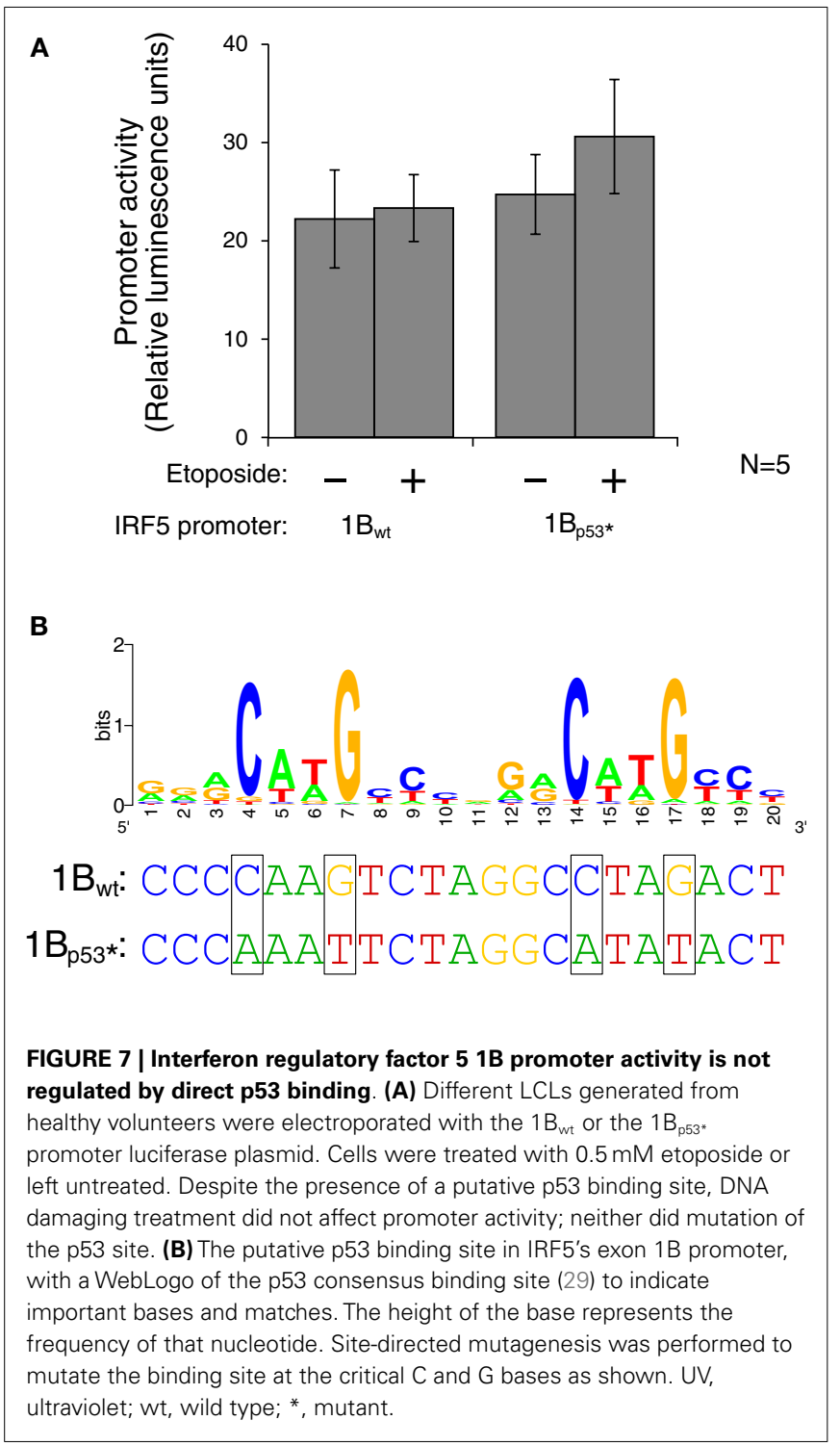

the $1 \mathrm{D}$ exon by $714 \mathrm{bp}$. The results of their luciferase assay cannot therefore be compared with the promoter analysis performed in this work. This work narrows the DNA regions studied and separates them into each of the four unique promoter elements, demonstrating that each are active promoters. This work also confirms that the $1 \mathrm{~A}$ promoter is the strongest and is activated by imiquimod, and that the $1 \mathrm{D}$ promoter is also strongly activated by this stimulus.

The ability of a cell to use and splice the $1 \mathrm{~B}$ exon is independent of its promoter usage. The $1 \mathrm{~B}$ promoter is active in persons with both the risk and protective polymorphisms at rs2004640, yet the protective sequence would result in a non-sense transcript, as splicing would not be possible. The risk $\mathrm{T}$ allele allows for the exon $1 \mathrm{~B}$ transcript to be spliced onto exon 2 and this is evidenced by the correlation between the risk $\mathrm{T}$ allele and increased levels of both IRF5 and exon 1B usage. The effects of the ability to use the $1 \mathrm{~B}$ promoter can also be seen in the increased responsiveness of the cells containing the risk allele to imiquimod. 
Interferon regulatory factor 5's $1 \mathrm{~B}$ promoter was predicted to contain a p53 binding site. The only promoter tested which increased in activity after inducing DNA damage was the $1 \mathrm{~B}$ promoter. The others showed a reduction in luciferase activity (data not shown). The mutated version of the $1 \mathrm{~B}$ promoter, which contained an altered p53 binding site, showed a slight increase in luciferase activity instead of a decrease, likely suggesting that any p53 binding to this promoter region is inhibitory. The $1 \mathrm{~B}$ promoter contains SP1, IRF4, TCF12, and EBF binding sites. EBF is a $\mathrm{B}$ cell-specific transcription factor (55). Further work is necessary to reveal the stimuli or cell types that use the $1 \mathrm{~B}$ promoter, as well as the combinations of transcription factors that drive transcription.

During cloning experiments dealing with exon $1 \mathrm{~B}$ and its promoter, several sequencing reactions showed $<100 \%$ sequence identity to the target. It was soon discovered that the primers were annealing to an upstream inverted repeat sequence. This repeat necessitated nested PCR for cloning the $1 \mathrm{~B}$ promoter. The repeat length is $1.8 \mathrm{kbp}$, and the two copies have $82.8 \%$ identity (56). The function of this repeat is unknown, but repeated sequences can act as decoys for transcription factors, lowering transcription of the intended target (57).

Usage of exon 1C is lower in cells with the rs2004640 autoimmune-risk factor. The $1 \mathrm{C}$ promoter contains putative SP1, IRF4, and EBF sites. It was the only promoter with AP1, Myc, and STAT2 binding sites. AP1 is a heterodimer of Fos and Jun proteins, among others, which are common in immune signal transduction (58). Myc is a proto-oncogene, and is essential for B cell proliferation (59). STAT2, when complexed with STAT1 and IRF9, is known to be activated by type I interferon (60). The STAT2 binding sites agree with a previous report on the $1 \mathrm{C}$ promoter of IRF5 by Mancl et al. which said the promoter is interferon responsive (61). The current analysis identified the same STAT2 binding site in the 1C promoter. The difference in the two analyses is the assumed placement of the initiation site. The analysis by Mancl et al. uses $5^{\prime} \mathrm{RACE}$ to determine the initiation site and they calculate the STAT2 binding site is $96 \mathrm{bp}$ downstream of that transcription initiation site. According to our initiation site - taken from the GenBank reference sequences which use exon $1 \mathrm{C}$ - the site was 47 bp upstream of the initiation site. Also of note, cells treated with imiquimod had lower $1 \mathrm{C}$ levels in proportion to the total IRF5.

Usage of exon 1D is lower in cells with the rs2004640 T allele and in cells with the CGGGG $4 \times$ allele. The $1 \mathrm{D}$ promoter evaluation showed only four transcription factors' binding sites: CTCF, IRF4, $\mathrm{NF} \kappa \mathrm{B}$, and SP1. NFKB is a target of TLR7 (62), and thus the promoter should be activated by imiquimod treatment. This was the case, and the $1 \mathrm{D}$ promoter nearly tripled in usage after imiquimod treatment. The IRF5 promoter analysis also showed a CTCF binding site. It is interesting that the $1 \mathrm{D}$ promoter is the furthest exon in the $5^{\prime}$ direction, and has putative CTCF sites, since CTCF is known to block the spread of CpG methylation by acting as an insulator (63). This may keep the other first exons - which are downstream and have high GC content - free from heterochromatin.

Interferon regulatory factor 5 is proapoptotic in a p53independent manner $(64,65)$. This does not preclude modulation by 553 , and a p53 enhancer site in exon 2 of IRF5 has been shown to activate IRF5 (66). p53 is a main regulator of apoptosis. Exon $1 B$ 's promoter was the only one with a putative p53 binding site, and cells with the rs 2004640 risk T allele are the only cells that can use exon 1B. Also, p53 can act as both a repressor and activator of transcription depending on local factors (67). However, in our assay, p53 did not significantly regulate the $1 \mathrm{~B}$ promoter.

Epstein-Barr virus infection is a necessary complicating factor when using LCLs as B cell lines. This is especially important since EBV has been shown to affect IRF5 function $(33,68)$. The effect of EBV in this study was limited by using EBV-infected LCLs as both our risk and protective cell lines. Since cell lines of both genotypes are transformed with EBV, the differences observed should be comparable and the effect of EBV excluded. However, given the importance of EBV infection in IRF5 activity and the development of lupus, viral effects cannot be simply discounted. There is a chance that differential effects of the risk polymorphisms on EBV infection processes are affecting IRF5 activity. These effects would be difficult to differentiate from direct effects on IRF5 activity. Either way, however, the results would be interesting and merit further investigation.

Autoimmune diseases are complex, multifactorial disorders with both genetic and environmental influences. The promoter variations examined in these experiments are strongly linked to risk for autoimmune diseases, including lupus, multiple sclerosis, and rheumatoid arthritis. Despite much effort, there has not been a dramatic effect associated with these polymorphisms, or really, most of the polymorphisms associated with autoimmune disease. Rather than diminishing their importance, however, the somewhat small effects observed here speak to the fine balance of the immune system. It is likely that even relatively small changes in gene regulation can lead to an imbalance in tolerance or activation of immune cells. Also, these genes are intertwined with other pathways and systems to provide a complex fabric controlling the level of immune responsiveness.

\section{MATERIALS AND METHODS PLASMID CONSTRUCTION AND LUCIFERASE ASSAY}

All vectors were sequenced to confirm the proper sequence. The plasmid pMax-GFP (Clontech) expresses the eGFP fluorescent protein, and it was used to measure transfection efficiency. Electroporations were performed using a Nucleofector device (Lonza). The electroporation buffer was $5 \mathrm{mM} \mathrm{KCl}, 15 \mathrm{mM} \mathrm{MgCl}_{2}, 15 \mathrm{mM}$ HEPES, $140 \mathrm{mM} \mathrm{Na} \mathrm{HPO}_{4}$, pH 7.2. Transfected cells were lysed and assayed for fluorescence levels before assaying luciferase activity using the Luciferase Assay System (Promega) on a Fusion $\alpha$ HT plate reader (Packard). Luciferase activity was evaluated in proportion to the transfection efficiency.

\section{CELL LINES}

Peripheral blood samples were obtained from healthy volunteers after informed consent following a protocol approved by the IRB at Brigham Young University. Peripheral blood mononuclear cells were isolated using lymphocyte separation medium (Mediatech). These cells were induced to form LCLs by incubation with EBV (B95-8 strain) and $2 \mathrm{ng} / \mathrm{ml}$ cyclosporin A (Tocris Biosciences). U937 and Jurkat cells were a kind gift from Dr. Kim O'Neill. Cell lines were maintained in RPMI (Sigma) with $10 \%$ fetal bovine serum (PerBio) with penicillin/streptomycin/amphotericin (Calbiochem) at $5 \% \mathrm{CO}_{2}$ and passaged at least weekly. 
GENOTYPING OF VOLUNTEERS AND FORMATION OF PAIRED SAMPLES Genomic DNA was extracted (Qiagen) from peripheral blood mononuclear cells and genotyped using TaqMan reagents Applied Biosystems (ABI) on a StepOnePlus real-time PCR machine (ABI) at the rs2004640 SNP (ABI SNP Assay C9491614). Homozygous risk or protective individuals were matched by gender and ethnicity. Heterozygotes were not included in the study. The primers and PCR conditions are in Table A1 in Appendix.

\section{CELL TREATMENTS}

The TLR7 ligand imiquimod (R-837) was used to stimulate cells for some experiments. Cells were treated for $24 \mathrm{~h}$ with $25 \mu \mathrm{g} / \mathrm{ml}$ imiquimod (InvivoGen). cDNA preparation, quantitative PCR, primers, probes, and conditions are described elsewhere in the Section "Materials and Methods." Etoposide was used at 0.1 and $1 \mathrm{mM}$ concentrations and applied for $48 \mathrm{~h}$. 5FU was used at $1.5 \mathrm{mg} / \mathrm{ml}$, and the activating antibodies to TRAIL and Fas were used at 1 and $5 \mu \mathrm{g} / \mathrm{ml}$, respectively. All treatments used $10^{6}$ cells per milliliter.

\section{CDNA LIBRARIES AND PCR}

About $8 \times 10^{6}$ cells were used for each condition in each experiment. cDNA preparations were made by extracting RNA using the RNaqueous system (Ambion), followed by DNase treatment (Promega). One thousand nanograms RNA was per condition was then reverse transcribed using SuperScript III reverse transcriptase (Invitrogen Life Technologies). One hundred nanograms cDNA preparations were used as template for quantitative PCR using TaqMan reagents (ABI), or SYBR green reagents For gene expression studies, input RNA levels were normalized using primers to the housekeeping gene GAPDH for SYBR green experiments and $\beta$-GUS for TaqMan experiments. For cloning of $5^{\prime}$ UTRs and promoters the template genomic DNA from Section "Genotyping of Volunteers and Formation of Paired Samples" was used, with the NEB High GC PCR kit. Primers were purchased from Integrated DNA Technologies. Sequences and PCR conditions are available in Table A1 in Appendix.

\section{SEQUENCING}

Plasmid sequencing used purified plasmid DNA and a primer upstream of the insertion site. Sequencing reactions used Big Dye terminator reagents and the 3730xl DNA analyzer (ABI). See Table A1 in Appendix for primers.

\section{STATISTICAL ANALYSIS}

A paired $t$-test was used to compare means for mRNA expression. Paired $t$-test was used for luciferase levels. An alpha value of 0.05 and two-tailed $p$ values were used in all cases. For experiments using more than two comparisons, ANOVA was used to determine if statistically significant differences were present. Statistical analysis was performed using Data Analysis Plus software (Keller Statistics). ANOVA was performed using the CSBJU online calculator (http://www.physics.csbsju.edu/stats/).

\section{PROMOTER ANALYSIS}

An analysis of the promoters for each of the four first exons of IRF5 was performed using the ENCODE ChIP-Seq data set (34) for determining actual binding factors on the genomic region, followed by determining a consensus site using the WebLogo data in FactorBook (35). The consensus site was then used to search the proximal promoters ( $\sim 200 \mathrm{bp}$ upstream from the +1 sites) to encounter a proposed binding site. Consensus site screening was performed using a custom searches of ambiguous nucleotides with MEGA (37). This involved searching using the find function, which allows for searching using the ambiguous nucleotide code. For example, a search for GAW would highlight both GAA and GAT.

\section{ACKNOWLEDGMENTS}

This work was supported by a Mentoring Environment grant and a Women's Research Initiative Grant from Brigham Young University. We would like to acknowledge the gift of multiple cell lines from Dr. Kim O’Neil at Brigham Young University.

\section{REFERENCES}

1. Kimura K, Wakamatsu A, Suzuki Y, Ota T, Nishikawa T, Yamashita R, et al. Diversification of transcriptional modulation: large-scale identification and characterization of putative alternative promoters of human genes. Genome Res (2006) 16(1):55-65. doi:10.1101/gr.4039406

2. Barnes BJ, Richards J, Mancl M, Hanash S, Beretta L, Pitha PM. Global and distinct targets of IRF-5 and IRF-7 during innate response to viral infection. J Biol Chem (2004) 279(43):45194-207. doi:10.1074/jbc.M400726200

3. Lien C, Fang CM, Huso D, Livak F, Lu R, Pitha PM. Critical role of IRF-5 in regulation of B-cell differentiation. Proc Natl Acad Sci U S A (2010) 107(10):4664-8. doi:10.1073/pnas.0911193107

4. Krausgruber T, Blazek K, Smallie T, Alzabin S, Lockstone H, Sahgal N, et al. IRF5 promotes inflammatory macrophage polarization and $\mathrm{T}(\mathrm{H}) 1-\mathrm{T}(\mathrm{H}) 17$ responses. Nat Immunol (2011) 12(3):231-8. doi:10.1038/ni.1990

5. Barnes BJ, Kellum MJ, Pinder KE, Frisancho JA, Pitha PM. Interferon regulatory factor 5, a novel mediator of cell cycle arrest and cell death. Cancer Res (2003) 63(19):6424-31.

6. Alonso-Perez E, Suarez-Gestal M, Calaza M, Kwan T, Majewski J, Gomez-Reino JJ, et al. Cis-regulation of IRF5 expression is unable to fully account for systemic lupus erythematosus association: analysis of multiple experiments with lymphoblastoid cell lines. Arthritis Res Ther (2011) 13(3):R80. doi:10.1186/ar3343

7. Stephens RM, Schneider TD. Features of spliceosome evolution and function inferred from an analysis of the information at human splice sites. $J \mathrm{Mol} \mathrm{Biol}$ (1992) 228(4):1124-36. doi:10.1016/0022-2836(92)90320-J

8. Kawasaki A, Kyogoku C, Ohashi J, Miyashita R, Hikami K, Kusaoi M, et al. Association of IRF5 polymorphisms with systemic lupus erythematosus in a Japanese population: support for a crucial role of intron 1 polymorphisms. Arthritis Rheum (2008) 58(3):826-34. doi:10.1002/art.23216

9. Brogna S, Wen J. Nonsense-mediated mRNA decay (NMD) mechanisms. Nat Struct Mol Biol (2009) 16(2):107-13. doi:10.1038/nsmb.1550

10. Sigurdsson S, Nordmark G, Göring HH, Lindroos K, Wiman AC, Sturfelt G, et al. Polymorphisms in the tyrosine kinase 2 and interferon regulatory factor 5 genes are associated with systemic lupus erythematosus. Am J Hum Genet (2005) 76(3):528-37. doi:10.1086/428480

11. Kozyrev SV, Lewén S, Reddy PM, Pons-Estel B; Argentine Collaborative Group, Witte T, et al. Structural insertion/deletion variation in IRF5 is associated with a risk haplotype and defines the precise IRF5 isoforms expressed in systemic lupus erythematosus. Arthritis Rheum (2007) 56(4):1234-41. doi:10.1002/art.22497

12. Kelly JA, Kelley JM, Kaufman KM, Kilpatrick J, Bruner GR, Merrill JT, et al. Interferon regulatory factor- 5 is genetically associated with systemic lupus erythematosus in African Americans. Genes Immun (2008) 9(3):187-94. doi:10. 1038/gene.2008.4

13. Graham RR, Kozyrev SV, Baechler EC, Reddy MV, Plenge RM, Bauer JW, et al. A common haplotype of interferon regulatory factor 5 (IRF5) regulates splicing and expression and is associated with increased risk of systemic lupus erythematosus. Nat Genet (2006) 38(5):550-5. doi:10.1038/ng1782

14. Dieguez-Gonzalez R, Calaza M, Perez-Pampin E, de laSerna AR, FernandezGutierrez B, Castañeda S, et al. Association of interferon regulatory factor 
5 haplotypes, similar to that found in systemic lupus erythematosus, in a large subgroup of patients with rheumatoid arthritis. Arthritis Rheum (2008) 58(5):1264-74. doi:10.1002/art.23426

15. Sigurdsson S, Padyukov L, Kurreeman FA, Liljedahl U, Wiman AC, Alfredsson $\mathrm{L}$, et al. Association of a haplotype in the promoter region of the interferon regulatory factor 5 gene with rheumatoid arthritis. Arthritis Rheum (2007) 56(7):2202-10. doi:10.1002/art.22704

16. Dieudé P, Guedj M, Wipff J, Avouac J, Fajardy I, Diot E, et al. Association between the IRF5 rs2004640 functional polymorphism and systemic sclerosis. Arthritis Rheum (2009) 60(1):225-33. doi:10.1002/art.24183

17. Kristjansdottir G, Sandling JK, Bonetti A, Roos IM, Milani L, Wang C, et al. Interferon regulatory factor 5 (IRF5) gene variants are associated with multiple sclerosis in three distinct populations. J Med Genet (2008) 45(6):362-9. doi:10.1136/jmg.2007.055012

18. Dideberg V, Kristjansdottir G, Milani L, Libioulle C, Sigurdsson S, Louis E, et al. An insertion-deletion polymorphism in the interferon regulatory factor 5 (IRF5) gene confers risk of inflammatory bowel diseases. Hum Mol Genet (2007) 16(24):3008-16. doi:10.1093/hmg/ddm259

19. Miceli-Richard C, Comets E, Loiseau P, Puechal X, Hachulla E, Mariette X. Association of an IRF5 gene functional polymorphism with Sjogren's syndrome. Arthritis Rheum (2007) 56(12):3989-94. doi:10.1002/art.23142

20. Feng D, Stone RC, Eloranta ML, Sangster-Guity N, Nordmark G, Sigurdsson S, et al. Genetic variants and disease-associated factors contribute to enhanced interferon regulatory factor 5 expression in blood cells of patients with systemic lupus erythematosus. Arthritis Rheum (2010) 62(2):562-73. doi:10.1002/art.27223

21. Niewold TB, Kelly JA, Flesch MH, Espinoza LR, Harley JB, Crow MK. Association of the IRF5 risk haplotype with high serum interferon- $\alpha$ activity in systemic lupus erythematosus patients. Arthritis Rheum (2008) 58(8):2481-7. doi:10.1002/art.23613

22. Hedl M, Abraham C. IRF5 risk polymorphisms contribute to interindividual variance in pattern recognition receptor-mediated cytokine secretion in human monocyte-derived cells. J Immunol (2012) 188(11):5348-56. doi:10. 4049/jimmunol.1103319

23. Sigurdsson S, Göring HH, Kristjansdottir G, Milani L, Nordmark G, Sandling $\mathrm{JK}$, et al. Comprehensive evaluation of the genetic variants of interferon regulatory factor 5 (IRF5) reveals a novel 5 bp length polymorphism as strong risk factor for systemic lupus erythematosus. Hum Mol Genet (2008) 17(6):872-81. doi:10.1093/hmg/ddm359

24. Nordmark G, Kristjansdottir G, Theander E, Eriksson P, Brun JG, Wang C, et al. Additive effects of the major risk alleles of IRF5 and STAT4 in primary Sjogren's syndrome. Genes Immun (2008) 10(1):68-76. doi:10.1038/gene.2008.94

25. Fan JH, Gao LB, Pan XM, Li C, Liang WB, Liu J, et al. Association between IRF-5 polymorphisms and risk of acute coronary syndrome. DNA Cell Biol (2010) 29(1):19-23. doi:10.1089/dna.2009.0929

26. Mancl ME, Hu G, Sangster-Guity N, Olshalsky SL, Hoops K, Fitzgerald-Bocarsly $\mathrm{P}$, et al. Two discrete promoters regulate the alternatively spliced human interferon regulatory factor-5 isoforms. Multiple isoforms with distinct cell typespecific expression, localization, regulation, and function. J Biol Chem (2005) 280(22):21078-90. doi:10.1074/jbc.M500543200

27. Niewold TB, Clark DN, Salloum R, Poole BD. Interferon alpha in systemic lupus erythematosus. J Biomed Biotechnol (2010) 2010:8. doi:10.1155/2010/948364

28. Yanai H, Chen HM, Inuzuka T, Kondo S, Mak TW, Takaoka A, et al. Role of IFN regulatory factor 5 transcription factor in antiviral immunity and tumor suppression. Proc Natl Acad Sci U S A (2007) 104(9):3402-7. doi:10.1073/pnas. 0611559104

29. Guthridge JM, Clark DN, Templeton A, Dominguez N, Lu R, Vidal GS, et al. Effects of IRF5 lupus risk haplotype on pathways predicted to influence B cell functions. J Biomed Biotechnol (2012) 2012:594056. doi:10.1155/2012/ 594056

30. Poole BD, Scofield RH, Harley JB, James JA. Epstein-Barr virus and molecular mimicry in systemic lupus erythematosus. Autoimmunity (2006) 39(1):63-70. doi:10.1080/08916930500484849

31. Poole BD, Templeton AK, Guthridge JM, Brown EJ, Harley JB, James JA. Aberrant Epstein-Barr viral infection in systemic lupus erythematosus. Autoimmun Rev (2009) 8(4):337-42. doi:10.1016/j.autrev.2008.12.008

32. James JA, Robertson JM. Lupus and Epstein-Barr. Curr Opin Rheumatol (2012) 24(4):383-8. doi:10.1097/BOR.0b013e3283535801
33. Martin HJ, Lee JM, Walls D, Hayward SD. Manipulation of the toll-like receptor 7 signaling pathway by Epstein-Barr virus. J Virol (2007) 81(18):9748-58. doi:10.1128/JVI.01122-07

34. Gelfand Y, Rodriguez A, Benson G. TRDB - the tandem repeats database. Nucleic Acids Res (2007) 35(Database issue):D80-7. doi:10.1093/nar/gkl1013

35. el-Deiry WS, Kern SE, Pietenpol JA, Kinzler KW, Vogelstein B. Definition of a consensus binding site for p53. Nat Genet (1992) 1(1):45-9. doi:10.1038/ ng0492-45

36. Lee TH, Maheshri N. A regulatory role for repeated decoy transcription factor binding sites in target gene expression. Mol Syst Biol (2012) 8:576. doi:10.1038/msb.2012.7

37. Olivier M, Hollstein M, Hainaut P. TP53 mutations in human cancers: origins, consequences, and clinical use. Cold Spring Harb Perspect Biol (2010) 2(1):a001008. doi:10.1101/cshperspect.a001008

38. Vesuna F, Winnard P Jr, Raman V. Enhanced green fluorescent protein as an alternative control reporter to Renilla luciferase. Anal Biochem (2005) 342(2):345-7. doi:10.1016/j.ab.2005.04.047

39. Su AI, Wiltshire T, Batalov S, Lapp H, Ching KA, Block D, et al. A gene atlas of the mouse and human protein-encoding transcriptomes. Proc Natl Acad Sci U $S$ A (2004) 101(16):6062-7. doi:10.1073/pnas.0400782101

40. Di Domizio J, Blum A, Gallagher-Gambarelli M, Molens JP, Chaperot L, Plumas J. TLR7 stimulation in human plasmacytoid dendritic cells leads to the induction of early IFN-inducible genes in the absence of type I IFN. Blood (2009) 114(9):1794-802. doi:10.1182/blood-2009-04-216770

41. Bao M, Liu YJ. Regulation of TLR7/9 signaling in plasmacytoid dendritic cells. Protein Cell (2013) 4(1):40-52. doi:10.1007/s13238-012-2104-8

42. Ganguly D, Chamilos G, Lande R, Gregorio J, Meller S, Facchinetti V, et al. Self-RNA-antimicrobial peptide complexes activate human dendritic cells through TLR7 and TLR8. J Exp Med (2009) 206(9):1983-94. doi:10.1084/jem. 20090480

43. Bullock AN, Fersht AR. Rescuing the function of mutant p53. Nat Rev Cancer (2001) 1(1):68-76. doi:10.1038/35094077

44. Horvath MM, Wang X, Resnick MA, Bell DA. Divergent evolution of human p53 binding sites: cell cycle versus apoptosis. PLoS Genet (2007) 3(7):e127. doi:10.1371/journal.pgen.0030127

45. Liu HY, Hong YF, Huang CM, Chen CY, Huang TN, Hsueh YP. TLR7 negatively regulates dendrite outgrowth through the Myd88-c-Fos-IL-6 pathway. JNeurosci (2013) 33(28):11479-93. doi:10.1523/JNEUROSCI.5566-12.2013

46. Weber A, Zimmermann C, Mausberg AK, Kieseier BC, Hartung HP, Hofstetter $\mathrm{HH}$. Induction of pro-inflammatory cytokine production in thymocytes by the immune response modifiers Imiquimod and Gardiquimod ${ }^{\mathrm{TM}}$. Int Immunopharmacol (2013) 17(2):427-31. doi:10.1016/j.intimp.2013.06.023

47. Hu G, Barnes BJ. IRF-5 is a mediator of the death receptor-induced apoptotic signaling pathway. J Biol Chem (2009) 284(5):2767-77. doi:10.1074/jbc. M804744200

48. Londin ER, Keller MA, D’Andrea MR, Delgrosso K, Ertel A, Surrey S, et al. Whole-exome sequencing of DNA from peripheral blood mononuclear cells (PBMC) and EBV-transformed lymphocytes from the same donor. BMC Genomics (2011) 12:464. doi:10.1186/1471-2164-12-464

49. Rosenbloom KR, Sloan CA, Malladi VS, Dreszer TR, Learned K, Kirkup VM, et al. ENCODE data in the UCSC Genome Browser: year 5 update. Nucleic Acids Res (2012) 41(Database issue):D56-63. doi:10.1093/nar/gks1172

50. Hess J, Angel P, Schorpp-Kistner M. AP-1 subunits: quarrel and harmony among siblings. J Cell Sci (2004) 117(Pt 25):5965-73. doi:10.1242/jcs.01589

51. de Alboran IM, O’Hagan RC, Gärtner F, Malynn B, Davidson L, Rickert R, et al. Analysis of C-MYC function in normal cells via conditional gene-targeted mutation. Immunity (2001) 14(1):45-55. doi:10.1016/S1074-7613(01)00088-7

52. Bhattacharya S, Eckner R, Grossman S, Oldread E, Arany Z, D'Andrea A, et al. Cooperation of Stat 2 and p300/CBP in signalling induced by interferon-alpha. Nature (1996) 383(6598):344-7. doi:10.1038/383344a0

53. Akira S, Hemmi H. Recognition of pathogen-associated molecular patterns by TLR family. Immunol Lett (2003) 85(2):85-95. doi:10.1016/S0165-2478(02) 00228-6

54. Phillips JE, Corces VG. CTCF: master weaver of the genome. Cell (2009) 137(7):1194-211. doi:10.1016/j.cell.2009.06.001

55. Mori T, Anazawa Y, Iiizumi M, Fukuda S, Nakamura Y, Arakawa H. Identification of the interferon regulatory factor 5 gene (IRF-5) as a direct target for p53. Oncogene (2002) 21(18):2914. doi:10.1038/sj.onc.1205459 
56. Hande KR. Etoposide: four decades of development of a topoisomerase II inhibitor. Eur J Cancer (1998) 34(10):1514-21. doi:10.1016/S0959-8049(98) 00228-7

57. Longley DB, Harkin DP, Johnston PG. 5-Fluorouracil: mechanisms of action and clinical strategies. Nat Rev Cancer (2003) 3(5):330-8. doi:10.1038/ nrc1074

58. Tait SW, Green DR. Mitochondria and cell death: outer membrane permeabilization and beyond. Nat Rev Mol Cell Biol (2010) 11(9):621-32. doi:10.1038/ nrm 2952

59. Li M, He Y, Dubois W, Wu X, Shi J, Huang J. Distinct regulatory mechanisms and functions for p53-activated and p53-repressed DNA damage response genes in embryonic stem cells. Mol Cell (2012) 46(1):30-42. doi:10.1016/j.molcel.2012. 01.020

60. Mellor J. The dynamics of chromatin remodeling at promoters. Mol Cell (2005) 19(2):147-57. doi:10.1016/j.molcel.2005.06.023

61. Hu G, Mancl ME, Barnes BJ. Signaling through IFN regulatory factor-5 sensitizes p53-deficient tumors to DNA damage-induced apoptosis and cell death. Cancer Res (2005) 65(16):7403-12. doi:10.1158/0008-5472.CAN-050583

62. Valouev A, Johnson SM, Boyd SD, Smith CL, Fire AZ, Sidow A. Determinants of nucleosome organization in primary human cells. Nature (2011) 474(7352):516-20. doi:10.1038/nature 10002

63. Kuroyanagi H, Watanabe Y, Hagiwara M. CELF family RNA-binding protein UNC-75 regulates two sets of mutually exclusive exons of the unc-32 gene in neuron-specific manners in Caenorhabditis elegans. PLoS Genet (2013) 9(2):e1003337. doi:10.1371/journal.pgen.1003337

64. Chen W, Lam SS, Srinath H, Jiang Z, Correia JJ, Schiffer CA, et al. Insights into interferon regulatory factor activation from the crystal structure of dimeric IRF5. Nat Struct Mol Biol (2008) 15(11):1213-20. doi:10.1038/nsmb.1496

65. Barash Y, Calarco JA, Gao W, Pan Q, Wang X, Shai O, et al. Deciphering the splicing code. Nature (2010) 465(7294):53-9. doi:10.1038/nature09000
66. Zubovic L, Baralle M, Baralle FE. Mutually exclusive splicing regulates the Nav 1.6 sodium channel function through a combinatorial mechanism that involves three distinct splicing regulatory elements and their ligands. Nucleic Acids Res (2012) 40(13):6255-69. doi:10.1093/nar/gks249

67. Batteux F, Palmer P, Daëron M, Weill B, Lebon P. FCgammaRII (CD32)dependent induction of interferon-alpha by serum from patients with lupus erythematosus. Eur Cytokine Netw (1999) 10(4):509-14.

68. Ning S, Huye LE, Pagano JS. Interferon regulatory factor 5 represses expression of the Epstein-Barr virus oncoprotein LMP1: braking of the IRF7/LMP1 regulatory circuit. J Virol (2005) 79(18):11671-6. doi:10.1128/JVI.79.18.1167111676.2005

Conflict of Interest Statement: The authors declare that the research was conducted in the absence of any commercial or financial relationships that could be construed as a potential conflict of interest.

Received: 24 June 2013; accepted: 23 October 2013; published online: 07 November 2013.

Citation: Clark DN, Read RD, Mayhew V, Petersen SC, Argueta LB, Stutz LA, Till RE, Bergsten SM, Robinson BS, Baumann DG, Heap JC and Poole BD (2013) Four promoters of IRF5 respond distinctly to stimuli and are affected by autoimmune-risk polymorphisms. Front. Immunol. 4:360. doi: 10.3389/fimmu.2013.00360

This article was submitted to Molecular Innate Immunity, a section of the journal Frontiers in Immunology.

Copyright (C) 2013 Clark, Read, Mayhew, Petersen, Argueta, Stutz, Till, Bergsten, Robinson, Baumann, Heap and Poole. This is an open-access article distributed under the terms of the Creative Commons Attribution License (CC BY). The use, distribution or reproduction in other forums is permitted, provided the original author (s) or licensor are credited and that the original publication in this journal is cited, in accordance with accepted academic practice. No use, distribution or reproduction is permitted which does not comply with these terms. 


\section{APPENDIX \\ Table A1 | List of primers and PCR conditions.}

TAQMAN-BASED QUANTITATIVE PCR PRIMERS

IRF5 exon 2 RT fwd: CCACCTCAGCCCTACAAGAT

IRF5 probe: FAM-TCCAATGGCCCTGCTCCCAC-TAMRA

IRF5 exon 3 RT rev: CTCCTCTCCTGCACCAAAAG

IRF5 1A TaqMan RT fwd: ACGCAGGCGCACCGCAGACA

IRF5 1B RT fwd: AGCTGCGCCTGGAAAGCGAGC

IRF5 1C TaqMan RT fwd: AGGCGGCACTAGGCAGGTGCAAC

IRF5 1D RT fwd: GAGGCTCAGCCCGGATCTGC

IRF5 exon 1 probe: FAM-CCATGAACCAGTCCATCCCAGTGGCTCCCACC-

TAMRA

IRF5 exon 2 common RT rev: TCGTAGATCTTGTAGGGCTGAGGTGGCA

$\beta$-Glucuronidase fwd: CTCATTTGGAATTTTGCCGATT

$\beta$-Glucuronidase probe: FAM-TGAACAGTCACCGACGAGAG-TAMRA

$\beta$-Clucuronidase rev: CCGAGTGAAGATCCCCTTTTTA

Conditions: $52^{\circ} \mathrm{C}, 95^{\circ} \mathrm{C}$ for $10 \mathrm{~min}, 52$ cycles of $\left(95^{\circ} \mathrm{C}\right.$ for $15 \mathrm{~s}, 65^{\circ} \mathrm{C} *$ for

$1 \mathrm{~min}$ ) with $500 \mathrm{nM}$ primers, $250 \mathrm{nM}$ probe

SYBR green quantitative PCR primers and conditions

GAPDH fwd: TGCACCACCAACTGCTTAGC

GAPDH rev: GGCATGGACTGTGGTCATGAG

CCR7 fwd: GCTCCAGGCACGCAACTT

CCR7 rev: GACCACAGCGATGATCACCTT

Calreticulin fwd: GCAGCAGAAGGGGGTGGTGT

Calreticulin rev: GTCCTGGGGGCAGGGGAGAA

NOXA fwd: GCTGTCCGAGGTGCTCCAGTT

NOXA rev: AGCGTTCTTGCGCGCCTTCT

IRF5 fwd: CCACCTCAGCCCTACAAGAT

IRF5 rev: CTCCTCTCCTGCACCAAAAG

Conditions: $95^{\circ} \mathrm{C}$ for $10 \mathrm{~min}, 40$ cycles of $\left(95^{\circ} \mathrm{C}\right.$ for $15 \mathrm{~s}$ and $60^{\circ} \mathrm{C}$ for $\left.1 \mathrm{~min}\right)$

PROMOTER CLONING PRIMERS ${ }^{\dagger}$

IRF5 1A prom fwd: CTGCgctagcCAGGTCAGTGCGGGGC

IRF5 1A prom rev: CCTGagatctACTTCCGCGTCTTGCCGC

Conditions: $94^{\circ} \mathrm{C}$ for $30 \mathrm{~s}, 40$ cycles of $\left(94^{\circ} \mathrm{C}\right.$ for $15 \mathrm{~s}, 62.0^{\circ} \mathrm{C}$ for $1 \mathrm{~min}$,

$68^{\circ} \mathrm{C}$ for $\left.30 \mathrm{~s}\right), 68^{\circ} \mathrm{C}$ for $5 \mathrm{~min}$

IRF5 1B prom fwd: GCGCgctagcGACAGGTGGGTCCCGGCCGC

IRF5 1B prom rev: GCAGagatctGCGGACCCCGCCCTACTCCA

Nested PCR first round: IRF5 1A prom fwd + IRF5 1B prom rev

Conditions: $94^{\circ} \mathrm{C}$ for $30 \mathrm{~s}, 40$ cycles of $\left(94^{\circ} \mathrm{C}\right.$ for $15 \mathrm{~s}, 59.3^{\circ} \mathrm{C}$ for $1 \mathrm{~min}$,

$68^{\circ} \mathrm{C}$ for $\left.30 \mathrm{~s}\right), 68^{\circ} \mathrm{C}$ for $5 \mathrm{~min}$

Nested PCR second round: IRF5 1B prom fwd + IRF5 1B prom rev

Conditions: $94^{\circ} \mathrm{C}$ for $30 \mathrm{~s}, 40$ cycles of $\left(94^{\circ} \mathrm{C}\right.$ for $15 \mathrm{~s}, 66.0^{\circ} \mathrm{C}$ for $1 \mathrm{~min}$,

$68^{\circ} \mathrm{C}$ for $\left.30 \mathrm{~s}\right), 68^{\circ} \mathrm{C}$ for $5 \mathrm{~min}$

IRF5 1C prom fwd: TAGTgctagcGCTGGTTTCCTCAGGTCCT

IRF5 $1 \mathrm{C}$ prom rev: CAGAagatctCAGCCCTGCCCTGGCCT

Conditions: $94^{\circ} \mathrm{C}$ for $30 \mathrm{~s}, 40$ cycles of $\left(94^{\circ} \mathrm{C}\right.$ for $15 \mathrm{~s}, 60.8^{\circ} \mathrm{C}$ for $1 \mathrm{~min}$,

$68^{\circ} \mathrm{C}$ for $\left.2 \mathrm{~min}\right), 68^{\circ} \mathrm{C}$ for $5 \mathrm{~min}$

IRF5 1D prom fwd: ACATgctagCACCTGCTGCCTGTTGACC

IRF5 1D prom rev: TGGCagatctGTCATTTGACAACCCC

Conditions: $94^{\circ} \mathrm{C}$ for $30 \mathrm{~s}, 40$ cycles of $\left(94^{\circ} \mathrm{C}\right.$ for $15 \mathrm{~s}, 59.4^{\circ} \mathrm{C}$ for $1 \mathrm{~min}$,

$68^{\circ} \mathrm{C}$ for $\left.1 \mathrm{~min}\right), 68^{\circ} \mathrm{C}$ for $5 \mathrm{~min}$

pGL4 sequencing fwd: CTAGCAAAATAGGCTGTCCC

*Primer annealing temperatures were $60^{\circ} \mathrm{C}$ for $\beta$-glucuronidase; $65^{\circ} \mathrm{C}$ for IRF5, $1 \mathrm{~A}$, and $1 \mathrm{~B} ; 66^{\circ} \mathrm{C}$ for $1 \mathrm{C}$ and $69^{\circ} \mathrm{C}$ for $1 \mathrm{D}$.

${ }^{+} P C R$ for these GC-rich promoters was performed using a high-GC kit (NEB) according to package instructions, with 10\% enhancer solution included for all reactions except exon $1 D$.

All are listed in $5^{\prime}$ to 3 orientation. Restriction enzyme cut sites or overhangs are indicated in lowercase. FAM, fluorescein amidite; IRF5, interferon regulatory factor 5; RT, real time; TAMRA, carboxytetramethylrhodamine. 